\title{
Induction of Labor with Dinoprostone Vaginal Insert; Is it Safe and Effective in Term Pregnancy with Premature Rupture of Membranes?
}

\author{
Dinoproston Vajinal Ovül ile Doğum İndüksiyonu; \\ Erken Membran Rüptürlü Term Gebelikte Güvenli ve Etkili midir?
}

\author{
Illke TOPDAĞl AYDIN, ${ }^{a}$ \\ Halenur BOZDAĞ, ${ }^{b}$ \\ Egemen AYDIN, ${ }^{a}$ \\ Sedef KABACA, ${ }^{c}$ \\ Fulya GÖKDAĞLI, ${ }^{\mathrm{a}}$ \\ Kadir GÜZiN, ${ }^{b}$ \\ Necdet SÜER
}

aClinic of Obstetrics and Gynecology, Malkara State Hospital, Tekirdağ

'Department of Obstetrics and Gynecology, İstanbul Medeniyet University Göztepe Training and Research Hospital, İstanbul

'Clinic of Obstetrics and Gynecology, Nevşehir State Hospital, Nevşehir dDepartment of Obstetrics and Gynecology, Istanbu Medipol University

Faculty of Medicine, İstanbul

Geliş Tarihi/Received: 09.08.2015 Kabul Tarihi/Accepted: 11.11.2015

This study was presented as a poster in Turkey Maternal Fetal Medicine and Perinatology Perinatal Medicine 2015, 23-25 April 2015, İstanbul, Turkey.

Yazışma Adresi/Correspondence: Halenur BOZDAĞ

İstanbul Medeniyet University

Göztepe Training and Research Hospital,

Obstetrics and Gynecology, İstanbul,

TÜRKIYE/TURKEY

halenurbozdag@hotmail.com

\begin{abstract}
Objective: Our aim in this study is to compare the efficacy and safety of controlledrelease dinoprostone vaginal insert in patients with intact membranes and premature rupture of membranes (PROM). Material and Methods: Eighty-six term pregnants with singleton pregnancy, with no prior uterine scar, vertex presentation, bishop score $\leq 5$, were included in the study. Patients were divided into two groups as PROM patients (n:27) and patients with intact membranes (n:59). Labor induction with controlled-release dinoprostone vaginal insert was performed to all cases. The groups were compared with each other in terms of cervical ripening, success of the induction, adverse neonatal outcomes and presence of maternal side effects. Results: In the PROM group and the intact membrane group, the cervical ripening was completed at $4^{\text {th }}$ hours and at $6^{\text {th }}$ hours, respectively ( $\mathrm{p}=0.01$ and $\mathrm{p}=0.001$ ). The mean time to onset of active labor was 6,63 hours in the PROM group and 7,81 hours in the intact membranes group $(\mathrm{p}=0.1)$. There was no significant difference in low 1. and 5. minute Apgar scores, low umbilical artery $\mathrm{pH}$, administration to neonatal intensive care unit, and operative vaginal delivery between the two groups. Maternal vomiting, diarrhea, uterine tachysystole were not observed and there was no case of maternal or neonatal death. Conclusion: These data overall suggest that controlled-release dinoprostone insert use is effective and safe in patients with PROM just like in patients with intact membranes.
\end{abstract}

Key Words: Cervical ripening; dinoprostone; fetal membranes, premature rupture

ÖZET Amaç: Bu çalışmada amacımız, Erken Membran Rüptürü (EMR) ve intakt membranlı hastalarda kontrollü salınımlı dinoproston vajinal ovülün güvenilirliğini ve etkinliğini karşılaştırmaktır. Gereç ve Yöntemler: Bishop skoru $\leq 5$, baş geliş, önceden uterin skarı olmayan 86 term tekil gebe çalışmaya alındı. Hastalar EMR (n:27) ve intakt membranlı olarak (n:59) iki gruba ayrıldı. Tüm vakalara kontrollü salınımlı dinoproston ile doğum indüksiyonu uygulandı. Gruplar servikal olgunlaşma, induksiyon başarısı, olumsuz yenidoğan sonuçları ve anneye ait yan etkiler açısından karşılaştırıldı. Bulgular: EMR ve membranları sağlam grupta, servikal olgunlaşma sırasıyla 4 ve 6 . saatlerde tamamlandı ( $\mathrm{p}=0,01$ and $\mathrm{p}=0,001)$. Aktif doğum fazının ortalama başlama süresi EMR grubunda 6,63 saat ve membranları sağlam grupta 7,81 saaatidi ( $\mathrm{p}=0,1)$. Düşük 1. ve 5. dakika Apgar skoru, düşük umblikal arter $\mathrm{pH}$, yenidoğan yoğun bakım ünitesine başvuru ve operatif vajinal doğumda iki grup arasında istatistiksel fark yoktu. Annede kusma, diyare, uterin taşisistol gözlenmedi ve maternal neonatal ölüm olmadı. Sonuç: Bu veriler kontrollü salımlı dinoproston ovül kullanımının intakt membranlı hastalarda olduğu gibi EMR hastalarda da etkili ve güvenli olduğunu göstermektedir.

Anahtar Kelimeler: Servikal olgunlaşma; dinoproston; fetal membranlar, prematür rüptür

Turkiye Klinikleri J Gynecol Obst 2016;26(1):23-30

T erm prelabor rupture of fetal membranes (PROM) is defined as the rupture of fetal membranes before labor beyond 37 weeks of gestation. PROM complicates in about $8 \%$ of pregnancies and is associated with an increased risk of adverse maternal and neonatal outcome. ${ }^{1}$ Risks as- 
sociated with PROM are due to clinical or subclinical infection and inflammation. Major neonatal complications are early onset neonatal sepsis, low APGAR scores, intraventricular hemorrhage (IVH), neonatal encephalopathy and neonatal mortality. ${ }^{2}$ Maternal risks are chorioamnionitis and complications such as increased risk of caesarean section, wound infection and postpartum haemorrhage. ${ }^{3}$

The management of pregnancy with term PROM is challenging due to lack of strict criteria on optimal management and a common agreement consensus. But mainly, there are two options of managing term PROM which are expectant management and active approach including immediate induction of labor. Expectant management is recommended by National Institute for Health and Clinical Excellence: Guidance, while active management is advised by the American College of Obstetricians and Gynecologists in order to reduce the interval from PROM to delivery and decrease the risk of infectious complications. ${ }^{1,4}$ In the absence of any contraindication to vaginal delivery, active management can be carried out by induction of labor via using pharmacological or nonpharmacological methods. ${ }^{5,6}$

Oxytocin is the most common pharmacological agent used traditionally for induction of labor in women with PROM.

The condition of the cervix influences the success of labor induction. Labor induction in term pregnancy with unfavorable cervix is problematic and prostaglandin preparations such as dinoprostone or misoprostol are preferred as the method of cervical ripening and induction of labour. Among these prostaglandin preparations only dinoprostone is approved by the Food and Drug Administration to be used for cervical ripenning and induction of labor in live pregnancies. ${ }^{5}$ The issue which agent should be preferred in term PROM, and which one of them is more appropriate than the others to avoid adverse maternal or neonatal obstetric outcome is contraversial in the literature. ${ }^{7-13}$

Dinoprostone has been slowly taking the place of oxytocin in clinical practice. Because controlledrelease dinoprostone vaginal insert was not recom- mended in PROM cases historically, we aimed to evaluate the efficacy and safety of this agent in this group of patients in our clinic. Our aim in this study is to evaluate and compare the efficacy and safety of controlled-release dinoprostone vaginal insert in patients with intact membranes and premature rupture of membranes.

\section{MATERIAL AND METHODS}

This study was put into practice in Medeniyet University Göztepe Training and Research Hospital Gynecology and Obstetrics clinic between the dates March 2011 and March 2012. Eighty six pregnant patients who have completed 37 gestational weeks and whom labor induction with controlledrelease dinoprostone vaginal insert was performed, were included in the study. Local ethics committee approval was taken for this retrospective study. Written informed consent was obtained from the patients for this study.

Inclusion criteria were any women between 18-45 years having completed 37 gestational weeks due to last menstrual period or first trimester ultrasound, singleton pregnancy with cephalic presentation, parity no more than 3 , initial bishop score no more than 5 and having no more than 2 contractions in 30 minutes initial cardiotocographic assessment.

Exclusion criteria were non-cephalic presentation, cephalopelvic disproportion, multiple pregnancy, ex fetus, parity more than 3 , bishop score more than 5, abnormal initial cardiotocographic findings-nonreassuring fetal status, placenta previa, placental abruption or unexplained vaginal bleeding, asthma, any contraindication for prostaglandins, symptoms or signs of chorioamnionitis, history of uterine surgery.

Patients were divided into two groups:

The first group, defined as the study group, consisted of 27 term pregnant women with PROM. A sterile speculum examination confirming obvious leakage of amniotic fluid or a positive result to the AmniSure ROM test (Amnisure ${ }^{\circledR}$ lntl. Boston, USA) was considered as ruptured membranes. Our clinical policy was to perform active labor induc- 
tion if spontaneous labor did not initiate after 12 hours of expectant management. Prophylactic antibiotic therapy was initiated in all patients in this group.

The second group, defined as the control group, consisted of 59 patients with intact membranes. Any subject with doubt about amniotic fluid leakage in the initial sterile speculum examination and any subject that had spontaneous membrane rupture or amniotomy with vaginal insert being left in place during the course of the study were excluded from the study.

Demographic data and obstetric history of all patients were recorded. Fetal well-being was verified with fetal biophysic profile, using ultrasound and cardiotocography (CTG). Absence of chorioamnionitis was also verified with laboratory analysis and maternal, fetal clinical signs of chorioamnionitis.

Controlled-release prostaglandin (PG) E2 vaginal insert with retrieval system (Propess; Vitalis, Ankara, Turkey), which contains $10 \mathrm{mg}$ of dinoprostone and administers the medication at 0,3 $\mathrm{mg} / \mathrm{h}$, was used in the study.

For the assessment of cervical ripening, bishop score was recorded in two hours interval beginning from the application of the insert. A bishop score of 5 or more was accepted as completed cervical ripening. The insert was removed at the onset of the active phase of labor (cervical dilatation $\geq 5 \mathrm{~cm}$, in the presence of regular uterine contractions) or at the presence of maternal or fetal side effects. No other medication was not used for labor enhancement. The success of the induction was defined as the achievement of vaginal delivery within 24 hours of the insertion of the drug. The time to active phase was defined as the interval from insertion of dinoprostone pessary to the achievement of cervical dilation exceeding 5 centimeters or initiation of regular uterine contractions. Time to vaginal delivery was defined as the interval from insertion of PG E2 pessary to vaginal delivery.

Initial bishop score and parity were investigated as factors affecting time to vaginal delivery. Rates of vaginal delivery and cesarian section were recorded. Cesarean section indications were assessed. The causes of removal of the insert were recorded and evaluated. Fetal distress or non-reassuring fetal heart rate (FHR) were defined as abnormal baseline heart rate (more than 150 or less than 110), absence of accelerations, presence of late or variable decelerations in 30 minutes of CTG. Tachysystole was defined as having more than five contractions in 10 minutes of CTG. ${ }^{14}$

Furthermore, low 1. and 5. minute apgar scores (apgar score less than 7), fetal blood gas parameters showing fetal acidosis (umblical artery $\mathrm{pH}$ less than 7,2) and need for neonatal intensive care unit (NICU) were accepted as adverse neonatal outcomes.

Statistical analysis was performed with NCSS (Number Cruncher Statistical System) 2007 \& PASS (Power Analysis and Sample Size) 2008 Statistical Software (Utah, USA) program. Student t test was used to compare variables with normal distribution between the groups. Variables that weren't normally distributed were compared with Mann Whitney $U$ test between the groups and with Wilcoxon signed rank test between the subgroups. Qualitative data were compared with Chisquare test, Yates Continuity Correction and Fisher's Exact test. Statistical significance was excepted with a level of $\mathrm{p}<0.05$.

\section{RESULTS}

Our study was put into practice in Medeniyet University Göztepe Training and Research Hospital Gynecology and Obstetrics clinic between the dates March 2011 and March 2012. Eighty six patients were included in the study. Patients were divided into two groups. Group 1 consisted of 27 patients with premature rupture of membranes and Group 2 consisted of 59 patients with intact membranes.

There was no significant difference between the two groups in demographic properties or initial bishop scores. The mean gestational age of Group 1 was significantly shorter than group 2: $39.58 \pm 1.15$ and $40.55 \pm 1.15$ weeks respectively $(\mathrm{p}=0.001)$ (Table 1$)$. 
TABLE 1: Evaluation of the descriptive properties of the two groups.

\begin{tabular}{|lccc|}
\hline & $\begin{array}{c}\text { PROM } \\
\text { mean } \pm \text { SD }(\mathrm{n}=27)\end{array}$ & $\begin{array}{c}\text { Intact Membranes } \\
\text { mean } \pm S D(n=59)\end{array}$ & $p$ \\
Age (years) & $26.15 \pm 5.38$ & $26.56 \pm 5.37$ & 0.743 \\
Height $(\mathrm{cm})$ & $161.19 \pm 4.94$ & $160.25 \pm 5.13$ & 0.432 \\
Weight $(\mathrm{kg})$ & $78.33 \pm 8.32$ & $75.86 \pm 9.93$ & 0.265 \\
Gestational week & $39.58 \pm 1.15$ & $40.55 \pm 1.15$ & $0.001^{* *}$ \\
Parity & $0.63 \pm 0.69$ & $0.54 \pm 0.84$ & $0.314^{+}$ \\
Initial Bishop score & $3.11 \pm 0.97$ & $2.76 \pm 1.09$ & 0.132 \\
\hline
\end{tabular}

Student $t$ test; ${ }^{+}$Mann Whitney $U$ test; ${ }^{* *} p<0.01$.

Bishop score assessment was performed in two hours interval by the same researchers beginning from the application of the insert. There was no significant difference in initial bishop scores whereas the 2., 4., 6. and 8. hour bishop scores were significantly higher in the PROM group. There was no significant difference in the 10. and 12. hour bishop scores between the two groups (Table 2).
The mean time to onset of active labor was 6,63 hours in the PROM group and 7,81 hours in the intact membranes group. The mean time to vaginal delivery was 9,09 hours and 11,35 hours, respectively. There was no significant difference in time to onset of active labor and time to vaginal delivery between the two groups (Table 3).

The vaginal delivery ratio was $81.5 \%(22 / 27)$ and cesarean section ratio was $18.5 \%(5 / 27)$ in the PROM group, whereas these ratios for the intact membranes group are $67.8 \%(40 / 59)$ and $32.2 \%$ (19/59) respectively. There was no statistical difference in terms of type of delivery $(\mathrm{P}>0.05)$ (Table 3 ). The indications of cesarean delivery were also evaluated. The most common cesarean indication was acute fetal distress in the PROM group (3/5) and in the intact membranes group (6/19). The failure to progress was cesarean indication for 8 cases in the intact membranes group, whereas it wasn't occured in the PROM group.

\begin{tabular}{|c|c|c|c|c|c|}
\hline \multirow[b]{2}{*}{ Bishop scores (hours) } & \multicolumn{2}{|c|}{ PROM } & \multicolumn{2}{|c|}{ Intact Membranes } & \multirow[b]{2}{*}{$p$} \\
\hline & $\mathrm{n}$ & mean $\pm S D$ & $\mathrm{n}$ & mean $\pm S D$ & \\
\hline Initial bishop & 27 & $3.11 \pm 0.97$ & 59 & $2.76 \pm 1.09$ & 0.132 \\
\hline Bishop $2^{\text {nd }}$ hour & 27 & $4.30 \pm 1.77$ & 58 & $3.31 \pm 4.52$ & $0.015^{\star}$ \\
\hline Bishop $4^{\text {th }}$ hour & 26 & $5.69 \pm 2.05$ & 57 & $4.54 \pm 2.28$ & $0.010^{*}$ \\
\hline Bishop $6^{\text {th }}$ hour & 22 & $7.14 \pm 2.03$ & 51 & $5.12 \pm 2.64$ & $0.001^{* *}$ \\
\hline Bishop $8^{\text {th }}$ hour & 16 & $8.06 \pm 2.32$ & 44 & $5.91 \pm 2.54$ & $0.001^{* *}$ \\
\hline Bishop $10^{\text {th }}$ hour & 9 & $8.44 \pm 2.01$ & 34 & $7.18 \pm 2.56$ & 0.179 \\
\hline Bishop $12^{\text {th }}$ hour & 5 & $9 \pm 2.83$ & 26 & $7.35 \pm 2.83$ & 0.166 \\
\hline Bishop $14^{\text {th }}$ hour & 0 & - & 6 & $8.33 \pm 2.25$ & - \\
\hline Bishop $16^{\text {th }}$ hour & 0 & - & 3 & $10 \pm 1$ & - \\
\hline Bishop change & 27 & $5.44 \pm 2.47$ & 59 & $5.03 \pm 2.94$ & 0.713 \\
\hline
\end{tabular}

${ }^{+}$Mann Whitney U test; " $p<0.05 ;{ }^{* *} p<0.01$.

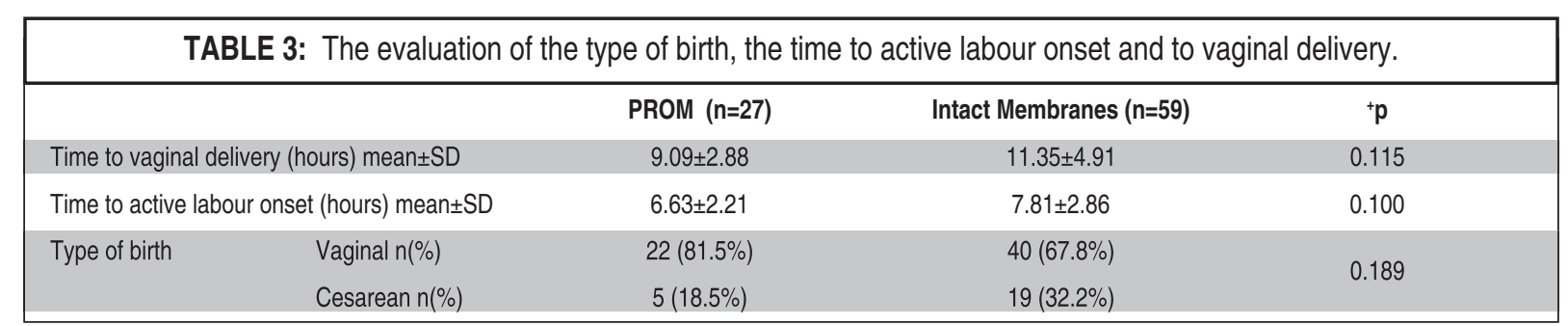

+ Mann Whitney U test. 


\begin{tabular}{|c|c|c|c|c|c|c|c|c|c|c|}
\hline \multirow[b]{2}{*}{ Time to vaginal delivery } & \multirow[b]{2}{*}{$\mathrm{n}$} & \multicolumn{3}{|c|}{ Parity } & \multirow[b]{2}{*}{$\mathrm{p}$} & \multicolumn{5}{|c|}{ Initial bishop score } \\
\hline & & $\begin{array}{l}\text { Nulliparous } \\
\text { mean } \pm S D \text { (median) }\end{array}$ & $\mathrm{n}$ & $\begin{array}{l}\text { Multiparous } \\
\text { mean } \pm \mathrm{SD} \text { (median) }\end{array}$ & & $\mathrm{n}$ & $\begin{array}{l}\text { Bishop 1-3 } \\
\text { mean } \pm S D \text { (median) }\end{array}$ & $\mathrm{n}$ & $\begin{array}{l}\text { Bishop 4-5 } \\
\text { mean } \pm S D \text { (median) }\end{array}$ & $\mathrm{p}$ \\
\hline PROM & 10 & $10,43 \pm 2,47$ & 12 & $7,97 \pm 2,79$ & $0,048^{*}$ & 14 & $9,71 \pm 3,00$ & 8 & $8,00 \pm 2,43$ & 0,194 \\
\hline Intact Membranes & 23 & $12,00 \pm 4,95$ & 17 & $10,46 \pm 4,85$ & 0,234 & 28 & $12,46 \pm 5,00$ & 12 & $8,73 \pm 3,67$ & $0,015^{*}$ \\
\hline
\end{tabular}

Mann Whitney U test; ${ }^{*} p<0.05$.

Time from induction to vaginal delivery was further evaluated in terms of parity and initial bishop score. That time interval was significantly longer in nullipars than multiparas in PROM group. But, there was no significant difference between parity and time to vaginal delivery in intact membranes group. In intact membranes group, time to vaginal delivery was significantly longer in patients with initial bishop score of 1-3, whereas there was no such difference in the PROM group (Table 4).

The incidence of uterine tachysystole was $18,5 \%$ (5/27) in PROM group and 10,2\% (6/59) in intact membranes group. There was no failed induction in PROM group whereas failed induction was observed in $10 \%$ of intact membranes group. In means of dinoprostone vaginal insert removal, there was no statistical difference between the two groups (Table 5).

There was no significant difference in fetal complications like low 1. and 5.minute Apgar scores (Apgar $\leq 7)$, low umbilical artery $\mathrm{pH}(<7,20)$, administration to neonatal intensive care unit, and operative vaginal delivery between the two groups (Table 6).

Maternal vomiting or diarrhea were not observed during the study. There was no need for tocolysis due to uterine tachysystole or fetal distress and there was no case of maternal or neonatal death.

\section{DISCUSSION}

Increased latency from membrane rupture to delivery is associated with increased rate of maternal and fetal complications. ${ }^{15,16}$ Thus, labor induction is recommended in cases that spontaneous labor doesn't initiate in 12 hours of expectant manage-

\begin{tabular}{|lccc|}
\hline \multicolumn{4}{|c|}{$\begin{array}{c}\text { TABLE 5: The evaluation of indications for } \\
\text { dinoprostone vaginal insert removal }\end{array}$} \\
\hline & PROM & Intact Membranes & \\
& $\mathbf{N}(\%)(\mathbf{n}=27)$ & $\mathbf{N}(\%)(\mathbf{n}=59)$ & $\mathbf{p}$ \\
$>5$ cm cervical dilation & $16(59.3 \%)$ & $33(55.9 \%)$ & 0.956 \\
Fetal distress & $4(14.8 \%)$ & $9(15.3 \%)$ & 1.000 \\
Maternal complication & $1(3.7 \%)$ & $2(3.4 \%)$ & 1.000 \\
Tachysystole & $5(18.5 \%)$ & $6(10.2 \%)$ & 0.310 \\
Failed induction & - & $6(10 \%)$ & 0.170 \\
\hline
\end{tabular}

Fisher's Exact test.

ment. A low bishop score is particularly predictive of failure in women who undergo induction of labor at term. Intervention to labor with unfavorable bishop score could result in increase of cesarian deliveries. ${ }^{17}$ So, cervical ripening is the prerequisite for successful labor induction. Thus, many mechanical and pharmacological methods have been tried for this purpose. Although oxytocin is the most commonly used agent for induction of labor, prostaglandins are recommended in cases of unripe cervix. ${ }^{18}$

Controlled-release prostaglandin E2 vaginal insert with retrieval system, containing $10 \mathrm{mg}$ of dinoprostone in timed-release formulation administers the medication at $0,3 \mathrm{mg} / \mathrm{h}$. An advantage of the insert over the other formulations is that it may be removed with the onset of active labor, or development of uterine hyperstimulation. The disadvantage of formulation is that it is relatively expensive, requires storage and becomes unstable at room temperature.

Controlled-release prostaglandin E2 vaginal insert was not recommended in patients with premature rupture of membranes in the past but its use has been recommended in PROM patients by ACOG labor induction guideline 2009. ${ }^{14}$ As its use 


\begin{tabular}{|c|c|c|c|}
\hline & $\begin{array}{c}\text { PROM } \\
\text { Mean } \pm S D(\text { median })\end{array}$ & $\begin{array}{l}\text { Intact Membranes } \\
\text { Mean } \pm S D \text { (median) }\end{array}$ & $+p$ \\
\hline Birth weight (g) & $3281.1 \pm 338.63$ & $3353 \pm 449.8$ & 0.456 \\
\hline Apgar 1. min & $8.30 \pm 1.38(8)$ & $8.39 \pm 1.76(9)$ & 0.564 \\
\hline Apgar 5. min & $9.67 \pm 0.48(10)$ & $9.56 \pm 1.04(10)$ & 0.442 \\
\hline pH & $7.27 \pm 0.064$ & $7.30 \pm 0.059$ & 0.115 \\
\hline $\mathrm{pCO}_{2}$ & $50.11 \pm 6.45$ & $49.03 \pm 9.12$ & 0.580 \\
\hline \multirow[t]{2}{*}{$\mathrm{HCO}_{3}$} & $19.86 \pm 2.35$ & $20.46 \pm 2.62$ & 0.312 \\
\hline & $N(\%)(n=27)$ & $N(\%)(n=59)$ & $\bullet p$ \\
\hline 1. minute Apgar score $<7$ & $1(3.7 \%)$ & $8(13.7 \%)$ & 0.262 \\
\hline 5. minute Apgar score $<7$ & $0(0 \%)$ & $2(3.4 \%)$ & 1.000 \\
\hline Umbilical artery $\mathrm{pH}<7.2$ & $2(7.4 \%)$ & $5(8.4 \%)$ & 1.000 \\
\hline Neonatal intensive care unit administration & $0(0 \%)$ & $4(6.7 \%)$ & 0.304 \\
\hline Operative vaginal delivery (vacuum extraction) & $1(3.7 \%)$ & $0(0 \%)$ & 1.000 \\
\hline
\end{tabular}

+ Mann Whitney U test; • Fisher's Exact test.

in patients with premature rupture of membranes is recently approved, there are few studies evaluating the efficacy and safety of controlled-release dinoprostone vaginal insert in patients with PROM.

Vaginal delivery is a good sign of efficacy of the metod used for cervical ripening in patients with an unfavorable cervix. In our study, the ratio of vaginal delivery in patients with intact membranes using PG E2 pessary was $67,8 \%$. That ratio was reported as $73-77,4 \%$ in other studies. ${ }^{19-21}$ The low vaginal delivery rate of patients with intact membranes in our study could be caused by the heterogeneity of indications for induction of labor.

The ratio of vaginal delivery in patients with PROM using PG E2 was reported as $81,4-93,8 \%$ by several researchers. ${ }^{9,21,22}$ In our study, the ratio of vaginal delivery in patients with PROM is $81,5 \%$. In a multicenter, prospective clinical study using controlled release vaginal insert, rate of cesarean section delivery was reported as $24.7 \%$ and $31.8 \%$ in term PROM cases and in term women with intact fetal membranes respectively. ${ }^{19}$ The researchers were notified that it didn't reach statistical difference. In another study, the rate of cesarean section was reported as $15.5 \%$ in patient with term PROM. ${ }^{23}$ In our study analysis, the cesarean delivery rate was found as $18.5 \%$ and $32.2 \%$ in term PROM group and intact fetal membranes group, respectively. We reported the most common indications for cesarean delivery as failure to progress in patients with intact membranes and acute fetal distress in PROM patients. There were no statistical significance between two groups. These results were consistent with other results in literature.

Time to vaginal delivery is evaluated as a sign of success of labor induction. It was reported as 14,1 hours in patients with intact mebranes and 12,5 hours in cases with PROM. ${ }^{21}$ Time from insertion to active labor onset was reported as $6,7-9,7$ hours in intact membranes and 5,3-8,5 hours in PROM in literature. ${ }^{21,24}$ In our study, time to active labor onset was 7,8 hours in patients with intact membranes and 6,6 hours in patients with PROM. Time to vaginal delivery was 11,35 hours in patients with intact membranes and 9,09 hours in patients with PROM. Active labor onset duration was compatible with literature. But time to vaginal delivery was shorter than those in literature, which can be partially explained by the lower initial bishop scores in the other studies.

We further evaluated time to vaginal delivery in terms of parity and initial bishop score. Mean time to vaginal delivery in nulliparas and multiparas were reported as 15,7 hours and 8,5 hours in patients with PROM, and 23,1 hours and 8,7 hours in patients with intact membranes respectively by 
Lyrenas et al. ${ }^{21}$ They reported that there were no statistical significance in terms of parity. In our study, time to delivery in nulliparas was significantly longer than multiparas in PROM group, whereas there was no significant difference due to parity in patients with intact membranes. There was no significant difference in time to vaginal delivery in PROM group due to initial bishop score, whereas time to vaginal delivery in patients with an initial bishop score of 1-3 was significantly longer than in patients with an initial bishop score of 4-5 in patients with intact membranes. These data should be further discussed in studies with larger number of patients.

One of the most important side-effects of labor induction is uterine tachysystole. The incidence of uterine tachysystole with controlled-release dinoprostone is reported between 5-16\% totally and $11,3 \%$ in PROM and $19,1 \%$ in intact membranes respectively in the literature. ${ }^{19,21,25}$ In our study, the incidence of tacysystole is $10,2 \%$ in patients with intact membranes and $18,5 \%$ in patients with PROM. These results were compatible with literature and none of the patients needed tocolysis. ${ }^{26}$ Failure of induction is reported as $1.8-7 \% .^{23,27}$ In our study, the vaginal insert was removed because of failure of induction in $7 \%$ of patients-all of which were among patients with intact membranes. There was no case of failed induction in the PROM group, which should be further discussed in larger studies.

Neonatal outcomes were also evaluated in our study. Low 1 . and 5. minute Apgar scores ( $\leq 7)$, low umbilical artery $\mathrm{pH}(<7,2)$ and administration to neonatal ICU were evaluated as fetal complications. Fetal acidosis (umbilical artery $\mathrm{pH}<7,2$ ) was found
$7,4 \%$ in PROM group and $8,4 \%$ in intact membranes group. Other indices of neonatal outcomes such as birth weight, umblical artery $\mathrm{pCO}_{2}$ and $\mathrm{HCO}_{3}$ were also evaluated. There was no statistically significant difference in any of the fetal complications between the two groups.

In a meta analysis, it was reported that neonatal complications, which were measured as apgar score $\leq 7$ and need for NICU, were not significantly different in the use of the dinoprostone vaginal insert compared with another prostaglandin. ${ }^{5}$ A retrospective study that included cases with PROM emphasized that no difference was found in neonatal outcome between two PG E2 forms (gel and vaginal insert form). Also, it was reported that there was no statistical difference in terms of operative vaginal delivery between two groups. ${ }^{28}$

There was no significant difference in vaginal delivery ratio between patients with intact membranes and PROM patients in our study. Time to vaginal delivery was found to be better correlated with parity in PROM patients whereas it was better correlated with initial bishop scores in patients with intact membranes.

\section{CONCLUSION}

There was no case of uterine rupture, maternal, fetal or neonatal death in our study. There was no significant difference in terms of low cord arterial $\mathrm{pH}$, low Apgar scores or neonatal intensive care unit admission between the two study groups. Within the scope of these, it was concluded that controlled release dinoprostone insert use for cervical ripening and labor induction is an effective and safe method in patients with PROM just like in patients with intact membranes.

\section{REFERENCES}

1. ACOG Committee on Practice Bulletins-Obstetrics. ACOG Practice Bulletin No. 80: premature rupture of membranes. Clinical management guidelines for obstetrician-gynecologists. Obstet Gynecol 2007;109(4): 1007-19.

2. Hagberg H, Wennerholm UB, Sävman K. Se- quelae of chorioamnionitis. Curr Opin Infect Dis 2002;15(3):301-6.

3. Rouse DJ, Landon M, Leveno KJ, Leindecker S, Varner MW, Caritis SN, et al; National Institute of Child Health And Human Development, Maternal-Fetal Medicine Units Network. The Maternal-Fetal Medicine Units cesarean registry: chorioamnionitis at term and its duration-relationship to outcomes. Am J Obstet Gynecol 2004;191(1):211-6.

4. National Collaborating Centre for Ws, Children's H. National Institute for Health and Clinical Excellence: Guidance. Antenatal Care: Routine Care for the Healthy Pregnant Woman. $2^{\text {nd }}$ ed. London: RCOG Press; 2008. p.428. 
5. Chen W, Xue J, Peprah MK, Wen SW, Walker $M, G a o Y$, et al. A systematic review and network meta-analysis comparing the use of Foley catheters, misoprostol, and dinoprostone for cervical ripening in the induction of labour. BJOG 2016;123(3):346-54.

6. Dögl M, Vanky E, Heimstad R. Changes in induction methods have not influenced cesarean section rates among women with induced labor. Acta Obstet Gynecol Scand 2016;95(1):112-5.

7. Austin SC, Sanchez-Ramos L, Adair CD. Labor induction with intravaginal misoprostol compared with the dinoprostone vaginal insert: a systematic review and metaanalysis. Am J Obstet Gynecol 2010;202(6):624.e1-9.

8. Güngördük K, Asicioglu $O$, Besimoglu $B$, Güngördük OC, Yildirm G, Ark C, et al. Labor induction in term premature rupture of membranes: comparison between oxytocin and dinoprostone followed 6 hours later by oxytocin. Am J Obstet Gynecol 2012;206(1): 60.e1-8.

9. Larrañaga-Azcárate C, Campo-Molina G, Pérez-Rodríguez AF, Ezcurdia-Gurpegui M. Dinoprostone vaginal slow-release system (Propess) compared to expectant management in the active treatment of premature rupture of the membranes at term: impact on maternal and fetal outcomes. Acta Obstet Gynecol Scand 2008;87(2):195-200.

10. Ozkan S, Calişkan E, Doğer E, Yücesoy I, Ozeren S, Vural B. Comparative efficacy and safety of vaginal misoprostol versus dinoprostone vaginal insert in labor induction at term: a randomized trial. Arch Gynecol Obstet 2009;280(1):19-24.

11. Tan BP, Hannah ME. Oxytocin for prelabour rupture of membranes at or near term. Cochrane Database Syst Rev 2000;(2): CD000157.

12. Tan BP, Hannah ME. WITHDRAWN: Prosta- glandins versus oxytocin for prelabour rupture of membranes at term. Cochrane Database Syst Rev 2007;(2):CD000159.

13. Tan BP, Hannah ME. Prostaglandins for prelabour rupture of membranes at or near term. Cochrane Database Syst Rev 2000;(2):CD000178.

14. ACOG Committee on Practice Bulletins-Obstetrics. ACOG Practice Bulletin No. 107: Induction of labor. Obstet Gynecol 2009;114(2 Pt 1):386-97.

15. Hannah ME, Ohlsson A, Farine D, Hewson SA, Hodnett ED, Myhr TL, et al. Induction of labor compared with expectant management for prelabor rupture of the membranes at term. TERMPROM Study Group. N Engl J Med 1996;334(16):1005-10.

16. Dare MR, Middleton P, Crowther CA, Flenady VJ, Varatharaju B. Planned early birth versus expectant management (waiting) for prelabour rupture of membranes at term (37 weeks or more). Cochrane Database Syst Rev 2006;(1):CD005302.

17. Xenakis EM, Piper JM, Conway DL, Langer O. Induction of labor in the nineties: conquering the unfavorable cervix. Obstet Gynecol 1997;90(2):235-9.

18. Ray DA, Garite TJ. Prostaglandin E2 for induction of labor in patients with premature rupture of membranes at term. Am J Obstet Gynecol 1992;166(3):836-43.

19. Zou LY, Fan L, Duan T, Wang ZL, Ma RM. [Clinical study on dinoprostone suppositories $0.8 \mathrm{~mm}$ used in cervical ripening and labor induction of women with term pregnancy of premature rupture of the membranes: a multicenter study]. Zhonghua Fu Chan Ke Za Zhi 2010;45(7):492-6.

20. Biem SR, Turnell RW, Olatunbosun O, Tauh $\mathrm{M}$, Biem HJ. A randomized controlled trial of outpatient versus inpatient labour induction with vaginal controlled-release prostaglandin-
E2: effectiveness and satisfaction. J Obstet Gynaecol Can 2003;25(1):23-31.

21. Lyrenas S, Clason I, Ulmsten U. In vivo controlled release of PGE2 from a vaginal insert $(0.8 \mathrm{~mm}, 10 \mathrm{mg})$ during induction of labour. BJOG 2001;108(2):169-78.

22. Ben-Haroush A, Yogev Y, Glickman H, Bar J, Kaplan B, Hod M. Mode of delivery in pregnancies with premature rupture of membranes at or before term following induction of labor with vaginal prostaglandin E2. Am J Perinatol 2004;21(5):263-8.

23. Lettau R, Hege G, Steldinger R. [Premature rupture of fetal membranes at term: an indication for induced labor with prostaglandins?]. Zentralblatt Gynakol 1995;117(3):121-5.

24. Kunt C, Kanat-Pektas M, Gungor AN, Kurt RK, Ozat M, Gulerman C, et al. Randomized trial of vaginal prostaglandin E2 versus oxytocin for labor induction in term premature rupture of membranes. Taiwan J Obstet Gynecol 2010;49(1):57-61.

25. Rath W. A clinical evaluation of controlled-release dinoprostone for cervical ripening--a review of current evidence in hospital and outpatient settings. J Perinat Med 2005; 33(6):491-9.

26. Ashwal E, Hiersch L, Melamed N, Manor Y, Wiznitzer A, Hod M, et al. Pre-induction cervical ripening: comparing between two vaginal preparations of dinoprostone in women with an unfavorable cervix. J Matern Fetal Neonatal Med 2014;27(18):1874-9.

27. Nicholson JM, Cronholm P, Kellar LC, Stenson $\mathrm{MH}$, Macones GA. The association between increased use of labor induction and reduced rate of cesarean delivery. $\mathrm{J}$ Womens Health (Larchmt) 2009;18(11):1747-58.

28. Vollebregt A, van't Hof DB, Exalto N. Prepidil compared to Propess for cervical ripening. Eur J Obstet Gynecol Reprod Biol 2002;104(2): 116-9. 